PAWEŁ PRZYŁĘCKI

Instytut Socjologii UŁ

\title{
DIALOG W POLITYCE. MIT CZY PRAGMATYZM NASZYCH CZASÓW?
}

\section{Wstęp}

łowo „dialog” stało się modne w XX wieku. Od momentu upadku systemu komunistycznego w Polsce politycy różnych opcji nawołują do dialogu politycznego, biskupi głoszą konieczność dialogu religijnego, instytucje publiczne i państwowe mówią o dialogu społecznym. W końcu filozofowie, a nawet psychologowie kładą nacisk na dialog międzyludzki. Wyróżniona tu forma i liczba różnych dialogów są jedynie nieskończoną egzemplifikacją pokazującą bogactwo tego słowa. Celem tej pracy jest przyjrzenie się współczesnemu dialogowi społecznemu i politycznemu, jaki obserwujemy na co dzień. Postaram się odpowiedzieć na pytanie, czy w ogóle dialog polityczny istnieje, a nawet czy jest możliwy, biorąc pod uwagę z jednej strony specyfikę polityki, jej teorię, jak i praktykę, a z drugiej strony zasady, jakimi powinien kierować się dialog. W pierwszej części pracy przedstawię istotę dialogu filozoficznego, a następnie wyróżnię cechy właściwe dialogu politycznego. Omówię również, jak zmieniało się podejście rządzących do rządzonych od czasów ancien régime, pokazując na tej bazie rozwój dialogowego podejścia w rządzeniu i komunikowaniu politycznym. W ostatniej części postaram się zarysować problemy współczesnego dialogu politycznego. 


\section{Istota dialogu filozoficznego}

Niezmiernie trudno jest podać definicję dialogu, która miałaby charakter uniwersalny. Jednakże bezsporne jest stwierdzenie, iż dialog ma charakter swoistej relacji międzyosobowej. Jeśli jest realizowany właściwie, przyjmuje formę osobowego spotkania ludzi ze sobą, w czym wyraża się wymiana zdań i poglądów. Dialog przybliża ludzi do siebie, pozwala im poznać się nawzajem, zrozumieć drugą osobę, daje możliwość dojścia do kompromisu, a nawet przekonania do własnych racji ${ }^{1}$.

Filozoficzne studia nad problematyką dialogu biorą swój początek w XX wieku i wiążą się z pracami Franza Rosenzweiga, Martina Bubera, Emmanuela Levinasa. Ich prace i studia podejmujące problematykę spotkania z Innym stały się podstawą do odróżnienia tego typu dialogu, nazywanego egzystencjalnym od typu dialogu intelektualnego, będącego pierwowzorem dialogu według Sokratesa. W myśli filozoficznej zaczęto wyraźnie odróżniać te dwa typy dialogu, które przez wielu myślicieli, jak na przykład przez Bubera, uważane są za wykluczające się nawzajem² .

Dla celów tej pracy, w której rozważana będzie możliwość prowadzenia dialogu w polityce, dokładniej omówię typ dialogu intelektualnego. W przeciwieństwie do dialogu egzystencjalnego prawda, do której powinni zmierzać interlokutorzy, jest obiektywna, absolutnie ważna i niezależna od indywidualnych interesów. Prawda nie zależy więc w dialogu intelektualnym od rozmówców, czy samego faktu, że komunikują się. Prawda ma charakter absolutu. Według Sokratesa celem dialogu powinno być dążenie do osiągnięcia prawdy o Dobru ${ }^{3}$. W wypadku dialogu egzystencjalnego celem jest prawda egzystencjalna, która ma charakter jednostkowy, subiektywny, a jednocześnie jest tworzona w procesie komunikacji. Tym samym przez sam fakt innego rozumienia Prawdy, do której dążą uczestnicy dialogu, należy uznać, iż podstawą wyjaśniania dialogowej istoty polityki, zakładając, iż taka jest możliwa, jest dialog Sokratejski .

Idea dialogu intelektualnego bliska była również Jürgenowi Habermasowi. Odpowiednikiem dialogowego podejścia na przykład w polityce może

Zob. J. Baniak, Różnorodność spojrzeń na dialog i na jego znaczenie dla ludzi, „Filozofia Dialogu” 2005, t. 3, s. 7.

Zob. W. Gromczyński, Dialog egzystencjalny i egzystencjalna komunikacja (Buber, Jaspers), [w:] Odkrywanie podmiotowości: podręcznik dla trenerów, red. L. Frydzińska-Świątczak, M. K. Stasiak, Łódź 2002, s. 26.

Zob. A. Pobojewska, o dialogu (w kontekście edukacji), [w:] Od twórczości do podmiotowości, red. M. K. Stasiak, L. Frydzińska-Świątczak, Łódź 2005, s. 37-38.

Dokładne rozróżnienie pomiędzy dialogiem intelektualnym a egzystencjalnym znajduje się w: A. Pobojewska, dz. cyt. 
być jego teoria działania komunikacyjnego, którą definiował „jako taki rodzaj interakcji, w których wszyscy uczestnicy wzajemnie zestrajają swe indywidualne plany działania i dlatego bez żadnych obwarowań zmierzają do realizacji swych illokucyjnych celów" ${ }^{\prime 5}$. Kładł on w ten sposób nacisk na rolę dialogu w komunikacji, której celem jest nie tylko rozmowa, ale również poznanie poglądów drugiej osoby. Jednak, aby było to możliwe, w dialogu muszą brać udział wolne osoby, które nawzajem postrzegają się podmiotowo $\mathrm{w}$ aspekcie poznawczym.

Nie każda rozmowa jest dialogiem. Aby mógł on zaistnieć konieczne jest spełnienie kilku warunków. Pierwszym z nich jest partnerstwo, świadczące o równouprawnieniu osób, a jednocześnie wyrażające się w uznaniu godności Drugiego. Osoby te nie muszą jednak zajmować takiej samej pozycji społecznej. Warunkiem dialogu intelektualnego jest przekazywanie sobie idei i opinii. Oznacza to tym samym, iż zaistnienie takiego dialogu jest możliwe, gdy strony mają różne poglądy, które mogą nawzajem komunikować. Niewiedza i indyferentność poznawcza są natomiast przeszkodą stojącą na drodze wzajemnej komunikacji. Postawa dialogiczna rozmówców wymaga od nich również otwartości, czyli gotowości przyjęcia prawdy, niezależnie skąd ona pochodzi. Czyli ważne jest to, co zostało powiedziane, a nie przez kogo. Odrzucanie czyichś poglądów tylko dlatego, że wywodzi się z innej opcji politycznej, czy jest wyznawcą innej religii, świadczy o zamkniętej postawie na dialog. Postawa otwartości jest warunkiem sine qua non zaistnienia dialogu, a jednocześnie oznacza, iż nikt z uczestników spotkania nie ma monopolu na prawdę. Dialog powinien również posiadać swój nadrzędny cel, w którego imieniu będzie prowadzona dyskusja. Na przykład w sporze dialog ma służyć wartości, jaką jest prawda i poznanie tego, co słuszne. Tym, co w dialogu liczy się najbardziej, to siła argumentów, a nie argument siły, a o wielkości rozmówców decyduje umiejętność rezygnacji z własnych przekonań, jeśli otrzyma się argumenty świadczące o byciu w błędzie. Oznacza to, iż partnerzy dialogu intelektualnego powinni mieć świadomość własnej niewiedzy i omylności, a tym samym być gotowi do zmiany stanowiska w odpowiedzi na racjonalne argumenty. Wreszcie należy pamiętać jeszcze o jednym istotnym warunku, jaki powinien być spełniony w dialogu, a mianowicie o odwadze wyjścia ku drugiej osobie, o wysłuchaniu i przeanalizowaniu tego, co do nas mówi ${ }^{6}$.

J. Habermas, Teoria działania komunikacyjnego, t. 1, przeł. A. Kaniowski, Warszawa 1999, s. 485.

Zob. W. Tyburski, Idea dialogu w dziejach filozofii, [w:] Filozofia Dialogu. Materiaty z sesji naukowej zorganizowanej w Toruniu w dniu 13 listopada 1999 r., red. M. Kallas, Toruń 2000, s. 16-17. 


\section{Dialog polityczny}

W tej części, zasadniczej dla mojej pracy, postaram się omówić kilka zagadnień. Dokonam omówienia przedmiotu polityki, jej zadań i celu, następnie podejmę się próby zarysowania elementów, z jakich powinien lub mógłby składać się dialog polityczny, powołując się na dekalog dialogu Leonarda Swidlera. Na koniec postaram się odpowiedzieć na pytanie, ile jest dialogu w polityce? Dokonam rozróżnienia na dialog instytucjonalny i dialog o charakterze personalnym, który z założenia winien być prowadzony przez poszczególnych reprezentantów narodu.

Polityka w potocznym współczesnym rozumieniu jest negatywnie odbierana. Działalność polityczna jest często kojarzona z przemocą, korupcją, manipulacją itd ${ }^{7}$. Jednakże w pierwotnym, platońskim znaczeniu, polityka była wartością „królewską”. I jak pisał jeden z największych filozofów, opiekuńczość ludzka, która opiera się na gwałcie jest tyranią „[...] a tę umiejętność wypasania trzód, która po dobrej woli chętnymi dwunogimi rządzi, nazwiemy umiejętnością polityczną. Kto tę umiejętność polityczną posiada i tę opiekę wykonywa, ten jest istotnie królem i politykiem" ${ }^{8}$. Pomimo że kwestia polityki zajmowała już Platona, to w rzeczywistości pojęcie to upowszechnił Arystoteles ze Stagiry, który uważał, iż człowiek jest „zwierzęciem politycznym", czyli jest ze swej natury stworzony do życia w społeczeństwie w zorganizowanej wspólnocie ludzkiej".

W literaturze przedmiotu nie ma zgody co do tego, czym właściwie jest lub powinna być polityka, właśnie ze względu na bogactwo znaczeń i wykorzystywanie tego słowa w różnych kontekstach. Z jednej strony polityka jest utożsamiana $\mathrm{z}$ konfliktem, władzą i hegemonią, z drugiej strony jest rozumiana jako sposób rozwiązywania problemów. W związku z tym coraz częściej rozróżnia się „politykę” od „polityczności”. Według Chantal Mouffe „polityczność” to „wymiar antagonizmu leżący u podstaw każdego ludzkiego społeczeństwa, przez „politykę" [rozumie - przyp. P. P.] natomiast zestaw praktyk i instytucji, które w obliczu wprowadzanego przez polityczność konfliktu tworzą porządek umożliwiający ludzkie współistnienie"10. Takie rozumienie „polityczności” rozumianej jako przestrzeń walki i antagonizmów nie jest jednakże przez wszystkich przyjmowane. Za przykład można by podać

\footnotetext{
A. Heywood, Politologia, przeł. B. Maliszewska, Warszawa 2008, s. 4-5.

Platon, Dialogi, t. 2, przeł. W. Witwicki, Kęty 1999, s. 527.

Zob. J. Potulski, Socjologia polityki, Gdańsk 2008, s. 23.

Ch. Mouffe, Polityczność. Przewodnik krytyki politycznej, przeł. J. Erbel, Warszawa 2008, s. 24.
} 
Hannah Arendt, dla której polityczność jest przestrzenią wolności, w której może zaistnieć debata publiczna ${ }^{11}$.

W tych dwóch - na pierwszy rzut oka przeciwstawnych - rozumieniach polityczności oraz polityki, moim zdaniem może zaistnieć dialog, jako forma wypracowywania pewnego consensusu. Oczywiście Hannah Arendt w swoim rozumieniu z góry przyjmuje dialogiczność form dyskursywnych w przestrzeni politycznej. Jednakże i w ujęciu Ch. Mouffe taka możliwość zaistnienia dialogu istnieje, choć niekoniecznie jest to proste. Dialog nie musi, a nawet nie powinien mieć miejsca tam, gdzie istnieje pełna jednomyślność, a właśnie tam, gdzie istnieje najwięcej sprzeczności. Tak też należy rozumieć istotę polityki, która pojawia się wówczas, gdy dochodzi do uzgadniania sprzecznych interesów. Jest ona takim stanowieniem ładu i porządku, który nie wybiera przemocy i przymusu, a ugodę ${ }^{12}$, będącą wynikiem dialogu pomiędzy stronami i przeciwstawnymi często poglądami. $W$ takim rozumieniu, które również tutaj przyjmuję, polityka jest pewną koniecznością, wynikającą z faktu koegzystencji różnych grup społecznych, o różnych interesach. Polityka jest zatem działaniem polegającym na uzgadnianiu tych interesów poszczególnych grup, zamieszkujących jedno terytorium, będących pod jedną władzą ${ }^{13}$, która jest sprawowana w imieniu wszystkich i dla dobra ogółu. Na zakończenie tych wywodów należy podkreślić, iż polityką nie jest tyrania. Tam, gdzie dochodzi do głosu przymus i przemoc, kończy się polityka, która może istnieć tylko wówczas, gdy mamy do czynienia z występowaniem suwerennej władzy ${ }^{14}$. Za politykę nie można również uważać walki o władzę, którą należy rozumieć po prostu jako walkę o przywództwo ${ }^{15}$.

Dialog był ważnym elementem filozofii i metafizyki, ale współcześnie jest przede wszystkim istotnym elementem kultury, a w jej obrębie polityki. Można wręcz stwierdzić, iż dialog w polityce, głównie pomiędzy państwami, zaczął być stosowany najpóźniej. Jego genezy należy szukać wraz z dojściem do głosu idei liberalizmu w gospodarce i polityce, głoszącej nadrzędną rolę wolności działania, w tym wolności jednostki. Takie przemiany w rozumieniu państwa i polityki jako monolitu ku pluralizmowi wymuszały stopniowo prowadzenie dialogu na różnych szczeblach zachowań politycznych ${ }^{16}$.

Zob. tamże.

B. Crick, W obronie polityki, przeł. A. Waśkiewicz, Warszawa 2004, s. 41.

Zob. tamże, s. 23, 28.

Zob. tamże, s. 38 .

Zob. tamże, s. 40 .

Zob. M. Szulakiewicz, Z. Karpus, Od redaktorów, [w:] Dialog w kulturze, red. M. Szulakiewicz, Z. Karpus, Toruń 2003, s. 11. 
222 


\section{O niemożliwości dialogu w okresie ancien régime}

Dialog nie znosi tyranii lub moglibyśmy rzec - tyrania nie znosi dialogu. Podobnie inne systemy polityczne, w których władza była lub jest oparta na autorytecie jednostki, nie budują swojej tożsamości w oparciu o dialog. Tym samym próżno byłoby szukać problematyki dialogu w filozofii politycznej wieków średnich czy nowożytnych do XX w. W ancien régime król był głową państwa, jego władcą, właściwym wcieleniem władzy politycznej, decydującym o losie poddanych. Władza w starożytności i średniowieczu nie była rozumiana jako tyrania, bo oznaczała, że władza taka jest najwyższa i doskonała. Dopiero jej sens zmienił się u Machiavellego, gdy władza absolutna zaczęła być utożsamiana właśnie z tyranią ${ }^{22}$. Jednakże samo słowo absolutyzm powstało dopiero w XVIII wieku i oznaczało władzę nie mającą nad sobą żadnej kontroli ${ }^{23}$. Machiaveli jest uważany za ojca realizmu politycznego, w znaczeniu, iż oddziela politykę od religii i etyki, przeciwnie niż Arystoteles. Jak twierdził, polityka nie ma nic wspólnego z moralnością, bo nie jest ani moralna, ani niemoralna, w polityce liczy się skuteczność, a nie zło czy dobro ${ }^{24}$. Tym samym sankcjonował zasadę "cel uświęca środki”, uznając przemoc za dozwoloną praktykę sprawowania władzy.

Jednakże wraz z upadkiem monarchii absolutnej, wraz ze ścięciem głowy króla, nastąpiły nowe czasy, można by rzec, używając marksowskiego sformułowania, zaczęło krążyć po Europie widmo, nie tyle komunizmu, ile pluralizmu. Władza przechodzi w ręce ludu, który powoli, choć sukcesywnie, odgrywa coraz większą rolę w państwie. Lud staje się, w miejsce głowy państwa, suwerenem. Choć jak twierdzi Michel Foucault „władza nie składa się $\mathrm{z}$ «woli» (indywidualnych czy zbiorowych), [...] ani też nie da się jej wywieść z interesów" ${ }^{25}$. Suwerenność ludowa jest według niego pewną abstrakcją, a abstrakcje nie są w stanie rządzić. Suwerenność może się sprawdzać tylko wówczas, gdy państwo ma fizycznego suwerena ${ }^{26}$. Po upadku monarchii władza uległa rozproszeniu. Foucault pytał: „Kto jest suwerenem? Jak jest on konstytuowany jako suweren? Jakie więzy posłuszeństwa wiążą jednostki z suwerenem?"27. Po rewolucji francuskiej zaczęło przeobrażać się rozumie-

\footnotetext{
Zob. G. Sartori, Teoria demokracji, przeł. P. Amsterdamski, D. Grinberg, Warszawa 1994, s. 239.

Zob. tamże, s. 240 .

Zob. H. Olszewski., Historia doktryn politycznych i prawnych, Warszawa 1982, s. 104.

Cyt za: M. Walzer, Samotna polityka Michela Foucaulta, [w:] „Nie pytajcie mnie kim jestem...”. Michel Foucault dzisiaj, red. M. Kwiek, Poznań 1998, s. 16.

Tamże.

Zob. cyt za: tamże.
} 
nie pojęcia władza. Już nie zawsze wiązała się ona z centrum, ale zaczęła stopniowo pochodzić od dołu, czyli od mas. Tutaj należy również szukać początków kształtowania się myśli dialogicznej. Pomimo iż tak naprawdę filozofia dialogu znalazła swoje akademicko-teoretyczne podłoże w wieku XX, to genezy przemian dla dialogu politycznego należy szukać w szerszym tle wydarzeń historycznych, jakie zachodziły w XIX w. Mam tu na myśli wzrost znaczenia ruchów narodowowyzwoleńczych, rozwój myśli liberalnej, rozwój kapitalizmu czy w końcu powstanie pierwszych ruchów emancypacyjnych, na przykład sufrażystek.

W czasach ancien régime dialog nie był prawomocnym narzędziem sprawowania władzy i ustalania relacji pomiędzy rządzącymi a rządzonymi właśnie ze względu na istotę suwerenności, kreśloną chociażby przez takich filozofów jak Jean Bodin. Podobnie było z wcześniejszą, średniowieczną zasadą państwa patrymonialnego, gdzie władca rządził na ziemi w imieniu Boga, a państwo traktował jako własność lub z późniejszą zasadą, powstałą we Francji Ludwika XIV - „Państwo to ja”. W ancien régime dialog nie był narzędziem do kształtowania polityki zagranicznej, rola państwa wiązała się z liczbą wojska i siłą, jakie ono prezentowało. Sposób prowadzenia polityki w tym okresie można by nazwać, używając określenia Emanuela Levinasa „tyranią powszechności”, która kryje się w zasadzie ogólności i wiąże się $\mathrm{z}$ unicestwieniem ,ja" ${ }^{28}$. Głos jednostki niezwiązanej z władzą był głuchy. Dominująca idea uniwersalizmu, będąca zarazem naturalnym wrogiem indywidualizmu, niosła ze sobą anonimowość i bezosobowość. Naturalne było, że w epoce uniwersalizmu, gdzie wszystko jest takie samo, nie było miejsca na inność - wszyscy traktowani byli tak samo, co oznacza tym samym, iż każdy z osobna nic nie znaczył $\mathfrak{l}^{29}$. Już od czasów Heraklita - jak twierdzi Levinas - bycie było związane z przemocą i wojną, która była atrybutem bycia, polegającym na tym, aby zmusić Drugiego „do grania roli na korzyść jakiejś całości wskazywanej przez rozum, religię lub historię ${ }^{30}$, co było tożsame z wyzbyciem się indywidualności. Podobnie uważał Karl Jaspers, pisząc, iż polityka zawsze „rozgrywała się między dwoma biegunami: możliwej przemocy i wolnego współistnienia" ${ }^{31}$. To polityka zagraniczna wyrastała w przeszłości z przemocy, natomiast współcześnie przemoc znalazła swoje odzwierciedle-

${ }^{28}$ M. Żardecka-Nowak, Relacja między etyka a polityka w kontekście filozofii Emanuela Levinasa, „Filozofia Dialogu” 2003, t. 1, s. 230.

Zob. J. A. Kłoczowski, Filozofia dialogu, Poznań 2005.

Bo B. Skarga, Wstęp, [w:] E. Levinas, Całość i nieskończoność. Esej o zewnętrzności, przeł. M. Kowalska, Warszawa 2002, s. XIV.

K. Jaspers, Filozofia egzystencji. Wybór pism, przeł. D. Lachowska, A. Wołkowicz, Warszawa 1990, s. 437. 
nie również w obrębie stosunków wewnętrznych państwa. Jaspers jednocześnie podkreślał, iż dążenie do dialogu w polityce jest pewną koniecznością. Zadaniem polityki poprzez dialog powinno być ograniczanie przemocy na rzecz ochrony prawa i wolności osobistej, gdyż tylko poprzez zapewnienie wolności politycznej człowiek może stać się pełnym człowiekiem ${ }^{32}$.

\section{Współczesne zastosowania dialogu w polityce}

Poniżej przedstawię przykłady stosowania dialogu w polityce. Są one wynikiem spostrzeżeń autora, nie roszczą jednak pretensji do bycia skończoną egzemplifikacją stosowania takiego dialogu w polityce, nazywanego $\mathrm{w}$ dokumentach dialogiem społecznym ${ }^{33}$. Jednakże częściej używać będę określenia dialog polityczny, czy dialog w polityce (tak jak w tytule pracy), dla podkreślenia, że we wszystkich rodzajach dialogu (często społecznego) biorą udział politycy. Tym samym używam tu również takiego określenia dla podkreślenia wagi polityki, którą rozumiem, za B. Crickiem, jako działanie polityczne, na podstawie którego przeciwstawne strony mogą dojść do porozumienia i pogodzenia przeciwstawnych interesów. Proponuję tu zastosować następujący podział dialogu politycznego, odnoszący się do trzech obszarów przestrzeni polityczno-społecznej. Są to:

a) Dialog prowadzony w obrębie Unii Europejskiej - jest to szeroka kategoria, może dotyczyć dialogu prowadzonego pomiędzy przywódcami państw i reprezentantami narodu. Może to być dialog prowadzony pomiędzy określonymi instytucjami europejskimi (Komisją, Parlamentem, Radą Unii i Komitetem Społeczno-Ekonomicznym) a europejskimi strukturami reprezentującymi związki zawodowe i pracodawców. Jednakże ograniczę się tutaj do omówienia dwóch rodzajów dialogu, powszechnie rozwijanego w UE i wspieranego przez ustawodawstwo wspólnotowe - dialogu społecznego i obywatelskiego. Te rodzaje dialogu można uznać za pewien model warty dalszego rozwijania, zarówno na poziomie europejskim, jak i międzynarodowym.

Zob. tamże, s. 440 .

W literaturze przedmiotu spotykamy się zawsze z określeniem dialog społeczny, a nie polityczny. Dialog społeczny najczęściej definiuje się jako formę debaty o interesach społecznych. Podkreśla się również, że choć częściej ma on charakter sformalizowany, to może być również nieformalny. W dialogu zinstytucjonalizowanym negocjacje zbiorowe są prowadzone przez specjalnie powołane do tego celu instytucje, rady czy komisje, działające na podstawie aktów prawnych lub przyjętych porozumień. 
b) Dialog krajowy, regionalny i lokalny - prowadzony pomiędzy przedstawicielami władzy, a reprezentantami grup społecznych i zawodowych $^{34}$.

c) Dialog elit politycznych - ograniczam się tutaj do wąskiego rozumienia dialogu na poziomie władzy i opozycji, który można zaobserwować podczas różnego rodzaju debat politycznych $\mathrm{w}$ parlamencie czy środkach masowego przekazu. W poprzedniej części pracy w skrócie zostały przedstawione powody, dla których dialog polityczny nie mógł zaistnieć na szerszą skalę $w$ polityce międzynarodowej, nie mówiąc o relacjach władcapoddani. Zostały również zarysowane przyczyny zmian o charakterze polityczno-społecznym, które wprowadzały stopniowo dialog do komunikacji politycznej, począwszy od XIX wieku. Próba budowy nowego ładu społecznopolitycznego, zwłaszcza po II wojnie światowej, opierała się na mocnym akcentowaniu potrzeby dialogu. W Polsce otwarcie się na dialog elit politycznych nastąpiło później, bo dopiero po upadku komunizmu, a jego efekty są różne i często trudne do oceny.

Zaproponowane przeze mnie dwa pierwsze obszary prowadzenia dialogu - zarówno na poziomie krajowym, jak i ponadkrajowym - mają charakter instytucjonalny. Taki dialog, który pokrótce omówię, bierze swoje źródło z dyrektyw unijnych i ustawodawstwa krajowego. Natomiast dialog polityczny pomiędzy przedstawicielami elit politycznych nie ma żadnego unormowania prawnego. Może on być, lecz często nie jest, elementem prowadzonego dyskursu i świadczy w rzeczywistości o kulturze politycznej polityka, jak i o jego szacunku do drugiej osoby. Ten rodzaj dialogu będzie dla mnie szczególnie istotny.

\subsection{Dialog prowadzony w obrębie Unii Europejskiej}

Możemy wyróżnić dwa podstawowe rodzaje dialogu prowadzonego w obrębie UE - są to dialog społeczny i obywatelski, posiadające prawne unormowania. Mechanizmy dialogu społecznego rozwijane są przynajmniej od lat osiemdziesiątych XX wieku. Dialog społeczny rozumiany jest jako dialog prowadzony pomiędzy pracodawcami i pracobiorcami. Ma on charakter autonomicznego dialogu dwustronnego. W dokumentach Komisji Europej-

\footnotetext{
${ }^{34}$ W literaturze dokonuje się rozróżnienia dialogu krajowego od regionalnego czy lokalnego. Wyróżnia się również inne rodzaje dialogu zinstytucjonalizowanego, na przykład branżowy. Jednakże dla celów tej pracy połączyłem wszystkie rodzaje dialogu prowadzonego przez instytucje państwowe w obrębie obowiązującego prawa, gdyż nie dążę tu do omówienia istoty poszczególnych form dialogu, a tylko do zobrazowania tego zjawiska i pokazania zmian, jakie zaszły w ostatnim wieku.
} 
skiej termin dialogu społecznego jest używany na określenie wszelkich form komunikowania się, współdziałania i wymiany poglądów, między związkami zawodowymi, a pracodawcami. Rola państwa natomiast sprowadza się tu do bycia mediatorem ${ }^{35}$.

Takie rozumienie dialogu społecznego, głównie pomiędzy pracownikami i pracodawcami, jest ostatnio rozszerzane w UE i zaczęło obejmować wszelkiego rodzaju organizacje i stowarzyszenia, a nawet społeczeństwo ${ }^{36}$. Taki rodzaj dialogu, w którym biorą udział organizacje pozarządowe (NGO), nazywamy obywatelskim. Rolą tego dialogu jest kształtowanie ładu socjalnego i promowanie demokracji partycypacyjnej. Zostaje więc podkreślona rola społeczeństwa w ustalaniu harmonii i pokojowej egzystencji pomiędzy różnymi grupami. Jednocześnie coraz częściej dialog obywatelski staje się uzupełnieniem dla dialogu społecznego i demokracji parlamentarnej.

Dialog społeczny i dialog obywatelski prowadzone w obrębie UE posiadają odpowiednie umocowanie prawne i wsparcie ze strony instytucji politycznych. Sposób prowadzenia takiego dialogu może być różny i ze względu na swój zamknięty charakter nie wiemy, ile jest w nim prawdziwego dialogu, opierającego się na poszanowaniu Drugiego, a ile zwykłej manipulacji. Jednakże sama idea poszerzania sfery publicznej, w rozumieniu J. Habermasa, jest godna naśladowania, zwłaszcza przez kraje z innych części świata. Podejście dialogowe w rozwiązywaniu problemów dotyczących zwykłego człowieka nie tylko uczy tolerancji i poszanowania Drugiego, ale daje wiedzę o złożonej istocie określonych problemów i poczucie odpowiedzialności za ich przebieg.

Należy zwrócić uwagę na fakt, iż przystąpienie Polski do UE, a nawet już sam proces przygotowań do integracji, przyczynił się również w naszym kraju do wzmożonej aktywności poszczególnych grup społecznych, które po latach komunizmu musiały ponownie nauczyć się prowadzenia dialogu. Jeszcze przed akcesją wielu partnerów społecznych angażowało się w instytucje dialogu społecznego na poziomie europejskim, biorąc na przykład udział $\mathrm{w}$ posiedzeniach różnych komitetów $\mathrm{w} \mathrm{UE}^{37}$. Są również głosy, że zasadę subsydiarności obowiązującą w UE powinno się uważać za istotny element dialogu społecznego. Tłumaczyć to można funkcją samorządności, która od-

Zob. J. Hausner, M. Marody, J. Rutkowski, J. Wilkin, A. Wojtyna, M. Zirk-Sadowski, Polski Talk Show: Dialog spoleczny a integracja europejska. EU-monitoring V, Kraków 2001, s. 123.

Tamże, s. 124.

J. Męcina, Dialog społeczny w Polsce a integracja z Uniq Europejska, Warszawa 2005, s. 34-35. 
zwierciedla relacje społeczne w społeczeństwie obywatelskim, czyli relacje między obywatelem a władzą, jednostką a społeczeństwem ${ }^{38}$.

Ważnym również rodzajem dialogu, który nie będzie tu omawiany, ze względów technicznych, jest dialog pomiędzy przywódcami państw, który określa się raczej jako dyplomację i sztukę prowadzenia negocjacji.

\subsection{Dialog krajowy, regionalny i lokalny}

Dialog krajowy w Polsce jest zasadą ustrojową, zapisaną w konstytucji. W preambule konstytucji czytamy: W trosce o byt i przyszłość naszej Ojczyzny [...] my, Naród Polski - wszyscy obywatele Rzeczypospolitej [...] ustanawiamy Konstytucję Rzeczypospolitej Polskiej jako prawa podstawowe dla państwa oparte na poszanowaniu wolności i sprawiedliwości, współdziałaniu władz, dialogu społecznym oraz na zasadzie pomocniczości umacniającej uprawnienia obywateli i ich wspólnot ${ }^{39}$. Z kolei w rozdziale I „Rzeczpospolita” art. 20 czytamy: Spoleczna gospodarka rynkowa oparta na wolności działalności gospodarczej, własności prywatnej oraz solidarności, dialogu $i$ wspótpracy partnerów społecznych stanowi podstawę ustroju gospodarczego Rzeczypospolitej Polskiej ${ }^{40}$. Z powyższych zapisów wynika, że dialog społeczny nie jest instrumentem rządzenia, który władza publiczna może stosować, gdy zechce. Władza jest konstytucyjnie zobowiązana do stosowania go. Choć można zadać sobie pytanie, w jakim stopniu ta zasada jest w praktyce realizowana?

W Polsce rangę prowadzenia dialogu w kwestiach społecznych podwyższyło powołanie do życia w 1994 roku Trójstronnej Komisji ds. Społeczno-Gospodarczych, gwarantującej partnerom społecznym współudział w negocjacjach z rządem. Komisja ta w 2001 roku została ustawowo usankcjonowana i wyposażona w szereg nowych kompetencji ${ }^{41}$. Widać tym samym, że w Polsce następuje instytucjonalizacja dialogu społecznego, począwszy od lat 90. Ten proces zapewne będzie dalej postępował, wraz z ogólną tendencją, jaka występuje w UE i tym, jak szybko zmienia się rzeczywistość polityczno-społeczna. Oczywiście należy podkreślić pozytywny wpływ takiej tendencji ku dialogicznej formie rozwiązywania sporów o charakterze społecznym, jednakże nie należy zapominać o wielu błędach i zaniedbaniach. Wiele raportów, które ostatnio ukazały się, wskazują wciąż na pozorność dialogu społecznego w Polsce. Ma on unormowania prawne, ale merytorycznie jest prowadzony źle. Często jest przejawem pozorności lub bezalternatywno-

\footnotetext{
P. Czajka, Subsydiarność jako forma dialogu spolecznego w świetle doświadczeń Unii Europejskiej, [w:] Dialog w kulturze, s. 433-434.

Konstytucja Rzeczypospolitej Polskiej z dnia 2 kwietnia 1997 r., Dz.U. 1997, Nr 78, poz. 483. Tamże.

Zob. J. Męcina, dz. cyt., s. 13.
} 
ści propozycji przedstawianych przed jednego z uczestników dialogu, najczęściej przez stronę rządową ${ }^{42}$. Taka forma dialogu jednakże, w odniesieniu do tego, co zostało powiedziane w pierwszej części pracy, nie jest w istocie dialogiem, gdyż nie bierze się pod szczególną uwagę zdania drugiej strony.

\subsection{Dialog elit politycznych}

W 1989 roku władzę w Polsce przejął obóz solidarnościowy walczący o prawo dla społeczeństwa do współdecydowania o własnym losie, na zasadzie dialogu. Chcę pokazać, ile jest dialogu w tym dyskursie, a ile zwykłej walki o władzę. Pytanie, jakie warto by sobie zadać, to czy politycy, często o rodowodzie solidarnościowym, rozumieją, czym jest poszanowanie godności Drugiego, tak istotnej w dialogu?

Nawet pobieżna analiza debat politycznych w mediach czy parlamencie daje jeden, bardzo zły obraz polskiej sceny politycznej. Politycy różnych opcji zbyt często stosują zniewagi i inwektywy w stosunku do drugiej osoby, o przeciwstawnych poglądach. W politycznej debacie, jak się okazuje, nie ma miejsca na inność, ważna jest własna racja, nawet za cenę poniżenia drugiej osoby. Autorzy cytowanej już przeze mnie pracy na temat dialogu społecznego w Polsce stwierdzają, że dyskurs społeczny cechują: „instrumentalizacja" - uczestnicy posługują się językiem pogardy i szukają zawsze winnych; „nieautentyczność” - dyskurs nie tworzy tożsamości; „rytualizacja” - nie ma mowy o wypracowaniu wspólnego zdania i rozwiązaniu problemu spornego; „prowincjonalizacja” - nie przypomina dyskursu prowadzonego w krajach wysoko rozwiniętych, o zakorzenionej od dawna kulturze demokracji ${ }^{43}$.

Oczywiście nie można stosować generalizacji, iż wszyscy dążą jedynie do udowodnienia własnych racji. Można również szukać przykładów polityków nawołujących do dialogu politycznego z poszanowaniem wszelkich zasad, jakimi dialog winien się kierować. Najczęściej jednak takie wezwania są przez oponentów krytykowane, gdyż nie biorą oni wiary w prawdziwe intencje takich osób. W 1995 roku ukazał się tekst w „Gazecie Wyborczej” o prawdę i pojednanie, podpisany wspólnie przez Adama Michnika i Włodzimierza Cimoszewicza. Proponowali oni rozpoczęcie w Polsce dialogu pomiędzy ludźmi różnych obozów. Aby mogło do tego dojść należy, jak twierdzili, zacząć myśleć o zawarciu pewnego kompromisu, który będzie również oznaczał legitymizację przeciwnika jako pełnoprawnego uczestnika dialogu na scenie politycznej. Autorzy tego apelu chcieli zerwać z ciągłym konfliktem,

Zob. J. Hausner, M. Marody i in., dz. cyt., s. 125-130.

Zob. tamże, s. 158. 
który nie pozwalał patrzeć w przyszłość i pracować nad istotnymi dla kraju kwestiami ${ }^{44}$.

Przyczyny, dla których w dyskursie polskiej polityki jest tak mało dialogu, mogą być rozmaite. Przede wszystkim wciąż żywa jest pamięć historyczna, która wielu nie pozwala zapomnieć, ale i wybaczyć współpracy z władzą komunistyczną. Ponadto istotnym jest słabość polskiej demokracji, która tak naprawdę została zapomniana w okresie PRL-u i musiała być na nowo odbudowywana po 1989 roku. Jednakże chciałbym wskazać na jeszcze jeden istotny element, który pośrednio wiąże się z pozostałymi - jest to dojście do głosu coraz większej rzeszy polityków populistycznych, którzy w imię własnych racji, pod przykrywką obrońców ludu, nie liczą się ze zdaniem innych. Polski populizm zawiera w sobie zarówno wrogość i nienawiść do przeciwników politycznych, często tych o rodowodzie komunistycznym, jak i walkę o dobra dla najmniej uposażonych, którzy w poprzednim okresie nie mieli dostępu do władzy. W moim przekonaniu, populizm zarówno ten o charakterze agrarnym i ekonomicznym, jak i populizm narodowy, nie zawiera w sobie form dialogu. Liczy się tylko własne zdanie i interes, albo „my”, albo „wy”. W takim dyskursie jest dużo oskarżeń i inwektyw, konieczność szukania wroga odpowiedzialnego za wszelkie zaniedbania i błędy. Może to być wróg wewnętrzny w postaci wyalienowanych elit politycznych lub zewnętrzny, jak Bank Światowy czy Niemcy (w okresie przed akcesją do UE bardzo często pojawiał się ten wątek w wystąpieniach posłów Ligi Polskich Rodzin) ${ }^{45}$.

Nawet pobieżna analiza polskiej sceny politycznej nie pozwala stwierdzić, iż jest prowadzony poprawny dialog polityczny pomiędzy przedstawicielami elit politycznych. Odwołując się do dekalogu dialogu według Swidlera, można stwierdzić, iż praktycznie żaden element nie ma zastosowania w polskim dyskursie elit politycznych, choć błędem byłoby uogólnianie tego twierdzenia do wszystkich aktorów sceny politycznej. Wydaje się, iż największym zagrożeniem dla dialogu jest brak zaufania do swojego rozmówcy. Zamiast pytań i argumentów pojawiają się od razu oskarżenia i podejrzenia. Coraz więcej jest pytań typu, czy to prawda, że Pan X kontaktował się, współpracował, działał na szkodę itd. Tego rodzaju pytania retoryczne stały się pewną zasadą stosowaną już nawet w oficjalnym dyskursie parlamentarnym. W polskim dyskursie nagminne stało się porównywanie własnych ide-

${ }^{44}$ Zob. M. Beylin, Spory pamięci. Analiza debaty prasowej, [w:] Rytualny chaos. Studium dyskursu publicznego, red. M. Czyżewski, S. Kowalski, A. Piotrkowski, Kraków 1997, s. 227-230.

45 Zob. P. Przyłęcki, Populizm na polskiej scenie politycznej na podstawie analizy treści wybranych sprawozdań sejmowych z roku 2002, [w:] Tożsamość kulturowa i polityczna Europy wobec wyzwań cywilizacyjnych, red. D. Walczak-Duraj, Łódź 2004, s. 216-253. 
ałów z praktyką partnera. Jeśli nie jest to praktyka zgodna z własnymi ideałami, ma miejsce wręcz natychmiastowa kontestacja poglądów oponenta. Wartością samą w sobie byłaby dla wielu polityków umiejętność przeżycia ideologii partnera od wewnątrz, o czym Seidler wspomina w X punkcie swojego dekalogu. Być może wówczas znikłaby mowa nienawiści charakterystyczna dla wielu polityków, którzy we własnym mniemaniu wiedzą, jakie zasady są najlepsze dla całego społeczeństwa. W końcu wartością byłoby dochodzenie do prawdy, nie tylko przez dialog, ale również poprzez lekturę i właściwe studiowanie, aby przestały pojawiać się w dyskursie generalizacje, które nie wnoszą nic poza podejrzeniami. To argumenty poparte dowodami powinny być bazą dla dialogu, a nie hipotezy, pytania retoryczne, oskarżenia, często tworzone na użytek chwili.

\section{Zakończenie}

W niniejszym opracowaniu dokonałem próby odpowiedzi na pytanie, czy dialog w polityce jest możliwy, a jeśli tak, to jakie są jego podstawy? Czy wynika on z potrzeby międzyludzkiej, opartej na szacunku do drugiej osoby, czy może jest to jedynie pragmatyzm naszych czasów, będący wynikiem przeobrażeń politycznych w XIX i XX wieku? Przeprowadzona przeze mnie pobieżna analiza występującego dialogu społecznego, a także analiza dyskursu na tematy polityczne, nie napawają optymizmem. Należy stwierdzić, iż jest zasadnicza różnica w stosowaniu form dialogowych w polityce. Częściej do jego stosowania dochodzi na poziomie krajowym i ponadkrajowym, natomiast rzadko można dialogowe podejście zauważyć w dyskursie politycznym. Można więc stwierdzić, iż dialog instytucjonalny ma charakter pragmatyczny ze względu na unormowania prawne. Obowiązujące dyrektywy unijne wytyczają pewne ścieżki nakazujące lokalnym politykom większą wrażliwość na problemy i opinie społeczne. Ocena dialogu politycznego prowadzonego na gruncie krajowym i lokalnym wypada już gorzej. Podkreśla się często dominującą rolę władzy, która częściej przedstawia własne warunki rozwiązania problemu, niż prowadzi prawdziwe negocjacje oparte na dialogu. Najgorzej przedstawia się dialog prowadzony pomiędzy politykami. Jest on niestety mitem lub pobożnym życzeniem. Zbyt dużo jest tu własnych racji, a zbyt mało chęci na zrozumienie drugiej strony. Taki dyskurs rzadko ma formę dialogiczną, natomiast częściej przyjmuje formę spektaklu będącego areną walki o „własną” prawdę, jednakże prawdę, która ma być narzucona innym.

Jak zostało wcześniej powiedziane, dialog może mieć miejsce właśnie dlatego, że istnieją różnice. Dlatego też można by uznać, że głównie w poli- 
tyce powinien być on możliwy. Jednak aby tak było, każdy z osobna powinien nauczyć się prowadzić dialog, a ku temu potrzebne jest zrozumienie, że własne racje nie są jedynymi. Wielu polskim politykom ciągle brakuje otwartości na to, co inne i nowe. U podstaw dialogu tkwi postulat ciągłej reinterpretacji prawd, które wydają się absolutne, a w rzeczywistości są efektem codzienności i różnych okoliczności. Dlatego tak ważne jest ostrożne wyrażanie sądów i nieferowanie wyroków, połączonych z oskarżaniem i dyskredytacją drugiej osoby. Tym samym można stwierdzić, iż dialog w polityce jest możliwy, ale trudny. W Polsce raczej raczkuje, ale jest nadzieja, że tak jak w niektórych krajach wysoko rozwiniętych, tak i w Polsce, będą zachodzić zmiany. 


\section{Abstract}

In the first part of the article, the author describes an issue of dialogue in philosophy. According to the author, two types of dialogue in philosophy can be distinguished - intellectual and existential. The first type is an archetype of Socratic dialogue; the second one makes references to the Bible. Socrates believed that the insight into one's own experiences can best be acquired through mutual, critical enquiry. When thinking Socratically, people discover that they cannot clearly define ideas and concepts they previously held with certainty. This awareness in turn inspires further curiosity and open-minded reflection. In this dialogue each partner must listen to the other as openly and sympathetically as they can in an attempt to understand the other's position as precisely and, as it were, as much from within, as possible. Such an attitude automatically includes the assumption that at any point we might find the partner's position so persuasive that, if we would act with integrity, we would have to change, and this change can be disturbing.

The author of this article appeals to the rules of Socratic dialogue to show how it is possible to transfer these rules to the dialogue in politics. An example of this dialogue in politics can be the dialogue of Decalogue of Leonard Swidler. On the base of his Decalogue, it can be stated that in political dialogue it is important to remember that the primary purpose of dialogue is to learn, that is, to change and grow in the perception and understanding of reality, and then to act accordingly. Each participant must come to the dialogue with absolute honesty and sincerity. Each participant must come to the dialogue with no hard-and-fast assumptions as to where the points of disagreement are. Dialogue can take place only on the basis of mutual trust.

In the last part of the article, the author shows the changes of power since the Middle Ages. It was described how the power of the king was centralised and strengthened. The absolutist power of the ruler has weakened since $19^{\text {th }}$ century. Democratic transformations made the power be transferred into the peoples' hands. On the basis of these changes, the author presents how the dialogue among politicians and dialogue among different actors of political space is led. The analysis of Polish political stage gives evidence of many barriers of proper dialogue. There is too much vituperation in public discourse. Politicians lead a war on arguments and they are not willing to accept the opposition's right to different views. 